\section{Magas kockázatú benignus prosztata- hiperpláziás betegek dióda aktivált Nd:YAG lézervaporizációja. Első tapasztalatok}

\author{
Bajory Zoltán dr., Oroszi Márton dr., Pajor László dr. \\ Szegedi Tudományegyetem, Urológiai Klinika, Szeged (igazgató: Bajory Zoltán dr.)
}

\begin{abstract}
ÖSSZEFOGLALÁS
Célkitűzés: A speciális lézervaporizáció rövid távú eredményességének értékelése magas kockázatú prosztata-hiperpláziás (BPH) betegekben.

Betegek és módszerek: 2015-ben dióda aktivált Nd:YAG lézerkészülék müködött klinikánkon. Tíz magas kockázatú BPH-s betegben végeztünk Nd:YAG lézervaporizációt. A szövődményekről és hatékonyságról személyes kontrollok és telefoninterjúk során szereztünk adatokat. Vizsgáltuk a mütéti időt, a PSA-változást, a prosztata méretét, az I-PSS-értékeket és a szövődményeket.

Eredmények: Az átlag mütéti idő hosszúnak, 95 percnek bizonyult, ez jelentősen több mint a transurethrálisan reszekált betegek szokásos átlag műtéti ideje. A PSA-értékben és a prosztatatérfogatban a csökkenés igazolta a beavatkozás hatékonyságát. A panaszok mérséklődését a növekvő I-PSS-pontok igazolták. Fontos, hogy szövődmény nem keletkezett a különben magas kockázatú betegekben.

Következtetés: A dióda aktivált Nd:YAG lézervaporizáció hatékony és biztonságos mútéti lehetőség a magas műtéti kockázatú BPH-s betegeknél.
\end{abstract}

KuLCSSZAVAK: PROSZTATA-HIPERPLÁZIA, ND:YAG, DIÓDA LÉEER, VAPORIZÁCIÓ

\section{BEVEZETÉS}

A fejlett ipari országokban az életkor meghosszabbodása általános jelenség. Az idősödő férfi lakosságot fokozottan terhelik a civilizációs betegségek, a magas vérnyomás, a cukor-, szív-, daganatos- és pszichés betegségek. A hibás táplálkozás, a mozgásszegény életmód miatt a hazai betegtársadalom szinte csokorban szenved ezektől, amelyen felül még a BPH is sújtja ezt a korcsoportot. Ez ritkán halálos kór, de az életminőséget jelentősen rontja. A betegség tünetei közismertté váltak, köszönhetően a fitoterápiás készítmények reklámozásának, bár a felismerés egyáltalán nem jelent egyben orvoshoz fordulást. Tudjuk, hogy a BPH tünetei hullámzóan bár, de

\section{DIODE ACTIVATED ND:YAG LASER VAPORISATION FOR HIGH RISK BENING PROSTATIC HYPERPLASIA PATIENTS. EARLY EXPERIENCES}

\section{SUMMARY}

Objective: The short-term outcome of specific laser vaporisation was evaluated in high risk patients.

Material and method: In 2015 a diode pumped Nd:YAG laser equipment was applied at our department. A retrospective review of the patient's database and phone interview were done about the complications and efficacy. We analysed the complications, PSA value, prostate size, duration of the operation and I-PSS score. Results: The mean operative time was 95 minutes, significantly higher than a usual TUR. The hospital stay was observed more than the prostatic average. The decrease in PSA level and in prostate volume demonstrated the effectivity of the procedure. The extended I-PSS score indicated the release in the complaints. Most importantly no side effects or complications were registered among this high risk population.

Conclusion: Diode pumped Nd:YAG laser vaporisation seems to be effective, safe surgical treatment option for high risk prostatic patients.

KEYWORDS: BENIGN PROSTATE HYPERPLASIA, ND:YAG, DIODE LASER, VAPORISATION

progresszíven romlanak és kezelés nélkül elóbb-utóbb teljes vizeletelakadást eredményeznek. Az első sürgős orvosi megjelenést még mindig túl gyakran a vizeletelakadás és persze a katéterbehelyezés indokolja. Pedig a BPH gyógyszerrel jól kezelhető, a mútét időpontja évekig kitolható.

A mútét begyakorolt és bevált módszere a transurethralis reszekció (TUR), és csak igen nagy méretnél a nyílt vagy laparoszkópos mútét. A nem operálható betegek számára fejlesztették ki az alternatív megoldásokat, ezek kisebb megterhelést jelentenek. A kezdeti lelkesedés után több alternatív beavatkozás kikopott a gyakorlatból a hatástalanság vagy a magas szövődményhányad miatt. llyen a prosztataspirál-behelyezés, a krioterápia, termoterápia, TUNA, intersticiális lézerkezelés. Az idő́k próbáját viszont kiállta a lézervaporizáció, igaz megterhelés 
tekintetében ez a legnagyobb alternatív beavatkozás (4).

Az első „green light” készülékek után jöttek a dióda lézert használók. A hátrányok lassították az elterjedést, mert anesztézia igénye van, hosszabb a mútéti idő és persze a beavatkozás drága. Jelentős előny viszont, hogy a vérzésveszély elenyésző, nincs TUR-szindróma, a pacemakert nem zavarja és maga a mútéti megterhelés kisebb. Ki kell emelni, hogy lézerrel olyan beteg is megoperálható, akinél a vérhígítók szedését szív- és érbetegség miatt nem vagy csak nagyon rövid időre lehet felfüggeszteni (1). A probléma súlyát jól jelzi, hogy évente a tartósan antikoagulált betegek 10\%-ában válik szükségessé valamilyen orvosi beavatkozás, közülük az egyik legvérzékenyebb a prosztatamútét. A kezelés felfüggesztése, de még kiváltása kismolsúlyú heparinnal is, fokozza a trombózisveszélyt, illetve a másik oldalról, ha fennmarad a terápiás vérhígítás, nagy a vérzés kockázata. A bevett gyakorlat, hogy a kumarin kezelést 3 , a warfarint 5 nappal a mútét előtt kismolsúlyú heparinra váltjuk és csak a beteg végleges gyógyulása után - rendszeres INR-ellenőrzés mellett - állítjuk vissza. Trombocitaaggregációgátlóknál külön probléma, hogy nincs megbízható laborvizsgálat, amely támpont lenne a vérzés szempontjából. Ajánlott, hogy a vérlemezke-gátlót a mútét előtt 5 nappal el kell hagyni és kismolsúlyú heparinra váltani. Bonyolítja a helyzetet, hogy a vérhígítók más gyógyszerekkel interakciót mutatnak és a gyakori alkoholos májbetegség mellett lebontásuk elhúzódhat. Biztonságosabb tehát olyan mútéti beavatkozást választani - ilyen a lézervaporizáció -, amely alacsony vérzéses kockázattal jár. Elvileg ezzel a technikával még az antikoagulált beteg is megoperálható, de ezt a különleges kockázatot csak extrém esetben szabad felvállalni.

\section{BETEGEK ÉS MÓDSZER}

\section{A készülék: dióda aktivált Nd:YAG lézer}

Új technikai megoldás, hogy a gyakorlatban használt Nd:YAG kristályt dióda lézer gerjeszti, így sebészi szempontból értékesebb sugár nyerhető (3). A vaporizációs energia jobban fokozható, könnyebb a fókuszálhatóság, a szövetek karbonizációja csökken. A készülék kézi darabja levegővel hütött, ez egyben elszívja a vaporizációs füstöt nyílt mútét esetén.

\section{A beavatkozás}

A mútéteket kivétel nélkül alsó húgyúti endoszkópos mútétekben gyakorlott urológusok végezték. Az azonosított, kőmetsző helyzetbe fektetett beteg, bőrfertőtlenítés és izolálás után megfelelő - ez laryngeális maszkos altatást vagy spinális érzéstelenítést jelent - anesztéziában részesült. Az eszköz, lézerkiegészítővel ellátott operációs cisztoszkóp, optikusan kerül bevezetésre, amelyben a lézerszál előre-hátra mozgatható és forgatható (2). A lézerszál vége újszerü kiképzéssel történt, nem végprizma téríti el merőlegesen a sugarat, hanem a szál elcsavarva tompaszögben irányítja a lézerfényt, ezért is kapta a „twister" szál elnevezést. Az új kiképzés előnye a hosszabb élettartam, mert a szál legtöbbször a végprizmánál ég el. A beavatkozásnál a biztonsági előírásokat maradéktalanul betartottuk, még az éber beteg és persze a személyzet is el volt látva védőszemüveggel. A twister szál végét a szövetektől minimális távolságra érdemes tartani a vaporizáció teljes tartama alatt, így a kiáramló lézer teljesítményét a folyadékban való elnyelődés sem rontja. Természetesen az eszköz videorendszerrel van

\section{1. ÁBRA: ENDOSZKÓPOS KÉPEK A PROSZTATA LÉZERVAPORIZÁCIÓRÓL}

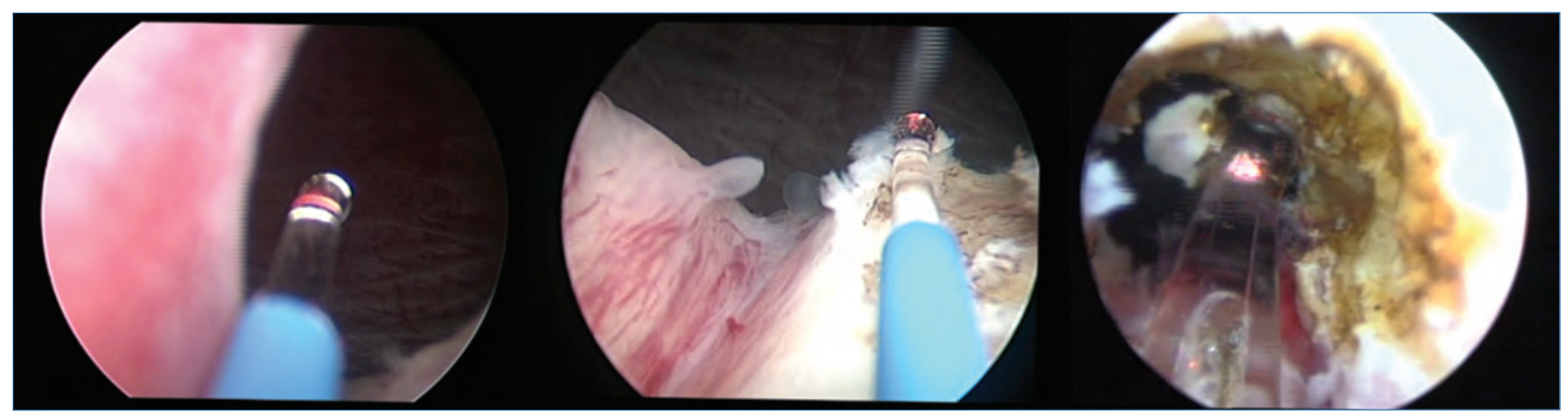

1. TÁBLÁZAT: A MAGAS KOCKÁZATOT MAGYARÁZÓ TÁRSBETEGSÉGEK

\begin{tabular}{|c|c|c|c|c|c|c|c|c|c|}
\hline K. J. & P. L. & Cs. Z. & Sz. B. & K. P. & Gy. M. & Sza. J. & Cs. J. & Sz. J. & K. M. \\
\hline $\begin{array}{l}\text { tüdőres. } \\
\text { tu. miatt } \\
\text { ASA }\end{array}$ & $\begin{array}{l}\text { angina } \\
\text { pect., } \\
\text { szívmútét, } \\
\text { ISZB pulm. } \\
\text { emb. diab. } \\
\text { mell., } \\
\text { syncumar }\end{array}$ & $\begin{array}{l}\text { hipertónia, } \\
\text { depresz- } \\
\text { szió, ASA }\end{array}$ & $\begin{array}{l}\text { hipertónia, } \\
\text { diab. mell., } \\
\text { ASA }\end{array}$ & $\begin{array}{l}\text { parox., } \\
\text { tadycardia, } \\
\text { hyper- } \\
\text { thyreosis, } \\
\text { vastag- } \\
\text { bél res. tu. } \\
\text { miatt, } \\
\text { demencia, } \\
\text { syncumar }\end{array}$ & $\begin{array}{l}\text { jobb láb } \\
\text { amp. } \\
\text { ér miatt, } \\
\text { syncumar }\end{array}$ & $\begin{array}{l}\text { diab.mell., } \\
\text { vestibulá- } \\
\text { ris lézió }\end{array}$ & $\begin{array}{l}\text { hipertónia, } \\
\text { demencia }\end{array}$ & $\begin{array}{l}\text { angina, } \\
\text { pacema- } \\
\text { ker, } \\
\text { pitvarfibr., } \\
\text { ISZB, mell- } \\
\text { kasi folya- } \\
\text { dék, ASA } \\
\text { nitrát }\end{array}$ & $\begin{array}{l}\text { angina, } \\
\text { szív- és } \\
\text { légzési } \\
\text { elégtelen- } \\
\text { ség, ISZB, } \\
\text { syncumar }\end{array}$ \\
\hline
\end{tabular}


összekapcsolva, így az operatőr és az asszisztencia monitoron követi a beavatkozást. A mútéti terület öblítése fiziológiás sóoldattal is lehetséges, saját gyakorlatunkban steril vizet használtunk, amelyet szobahőmérsékletüre állítottunk be, ez a szál végét folyamatosan hútötte. A hólyagnyaktól a colliculusig pásztázó vaporizáció folyamata alatt nyílik a prosztatikus húgycső, jól látszik a vizelési akadály eliminációja (1. ábra). A mútét céljától függően - palliáció vagy a teljes hiperplázia eltávolítása változik a vaporizáció időtartama. Jelen tanulmányunkban csak palliáció történt, hiszen a magas kockázatú betegek miatt a lehető legkisebb, de eredményes beavatkozás volt a cél. Ha vérzés jelentkezik, az ér lumene külön is elzárható. Ismerve a kezelés hátrányát, hogy szövettani anyag így nem nyerhető, magas PSA esetén TUR-ral mintát vettünk.

\section{A betegek}

Tekintve, hogy a készülék átmenetileg került a klinikánkra, olyan betegeket gyújtöttünk, akik társbetegségeik miatt mútétre nem, vagy csak nagy kockázattal lettek volna operálhatók. A tíz eset társbetegségeit az 1. táblázatban soroltuk fel. Közülük nyolcan vérhígítót szedtek, kumarint vagy vérlemezke-gátló aszpirint, ezek elhagyását a belgyógyász kockázatosnak itélte. A szokásos kumarinelhagyás és kismolsúlyú heparin adagolás minden esetben laborellenőrzés mellett történt. Az aszpirint csak a mútét előtt két napig hagytuk ki és a mútét másnapján folytattuk. Keringési, légzési zavarok, diabétesz, demencia gyakran előfordult, az utóbbi a posztoperatív zavartság miatt veszélyes.

A betegek közül hárman állandó katétert viseltek, egy beteg inkontinens volt, így náluk a panaszok felmérése az I-PSSpontokat és az uroflowmetriát nem használhattuk. A preoperatív pontok átlaga 8,3 volt, jól mutatta a panasz súlyos- ságát és ezt támasztotta alá az is, hogy a betegek reziduummal - átlagban $111 \mathrm{ml}$ - ürítették a hólyagot.

\section{Módszer}

Célunk, hogy az ismertetett módszerrel csökkentsük a hazai állandó katéterviselők számát, hiszen a biztos és lényegében kezelhetetlen fertőzés, a következményes égő, csípő fájdalom miatt ez sok szenvedést okoz.

Statisztikai feldolgozásnak ilyen alacsony esetszám mellett nem láttuk értelmét, helyette az összes beteg adatát táblázatba foglaltuk össze (2. táblázat). A retrospektív feldolgozás alapja a kórházi és járóbeteg-dokumentáció volt, illetve fél évvel a beavatkozás után minden beteggel telefonon interjút készítettünk. Hiányzó posztoperatív mérések esetén a beteget behívtuk és a szükséges vizsgálatokat pótoltuk. Ha szövettani mintavétel történt - négy esetben -, ez mindig hiperpláziát igazolt.

\section{Eredmények}

A magas kockázatú betegek közt életveszélyes szövődmény vérzés, TUR-szindróma, perforáció - nem keletkezett. A véralvadásgátlók óvatos korlátozása mellett is a Hgb-szint mútét után átlagosan 5\%-kal csökkent. A kórházi tartózkodás átlaga 5,5 nap, ez magas, valószínú jobb szervezéssel csökkenthető. Hosszú volt a mútéti idő is, átlagosan 95 perc, amely jóval több, mint a hagyományos TUR esetén, ezt a lézeres tapasztalatgyúités mérsékelheti. A PSA-csökkenés átlaga 42\%, amely közvetett bizonyíték a prosztataszövet eliminációjára. A transrectalis UH-val mért prosztatavolumen-csökkenés ennél jelentősebb lett, 66\%. A két érték tehát nem haladt párhuzamosan, amelynek oka lehet a nehezen

\section{TÁBLÁZAT: AZ OPERÁlt BETEGEK ADATAI (M - MÜTÉT)}

\begin{tabular}{|c|c|c|c|c|c|c|c|c|c|c|c|c|c|}
\hline Név & . J. & L. & & & K.P & & & & Sz. J. & K. I & & & \\
\hline Születési év & 1946 & 1941 & 1954 & 1956 & 1950 & 1953 & 1954 & 1952 & 1920 & 1952 & & & \multirow{5}{*}{$5 \%$ csökkenés } \\
\hline Kórházi ápolás (nap) & 5 & 10 & 5 & 6 & 4 & 3 & 5 & 3 & 10 & 4 & 55 & 5,5 & \\
\hline Mútéti idő (perc) & 60 & 75 & 190 & 135 & 120 & 120 & 60 & 90 & 90 & 45 & 985 & 95 & \\
\hline Hbg M előtt (g/l) & 155 & 148 & 165 & 156 & 138 & 121 & 159 & 121 & 103 & 146 & 141,2 & & \\
\hline Hbg M után (g/l) & 130 & 138 & 166 & 147 & 122 & 137 & 155 & 123 & 105 & 117 & 134,0 & & \\
\hline PSA M előtt & 2,43 & 24,0 & 7,34 & 3,75 & 4,18 & 23,4 & 2,1 & 17,2 & 23,7 & 6,5 & 114,6 & 11,4 & \multirow{2}{*}{$42,1 \%$ csökkenés } \\
\hline PSA M után & 1,02 & 18,0 & 4,23 & 2,49 & 3,71 & 17,37 & 2,1 & 5,2 & 15,2 & 3,1 & 72,4 & 7,2 & \\
\hline $\begin{array}{l}\text { Prosztataméret } \\
\text { M előtt (ml) }\end{array}$ & 70 & 30 & 85 & 50 & 62 & 76 & 24 & 81 & 82 & 30 & 590 & 59 & \multirow{2}{*}{$66 \%$ csökkenés } \\
\hline $\begin{array}{l}\text { Prosztataméret } \\
\text { M után (ml) }\end{array}$ & 41 & 22 & 32 & 27 & 43 & 60 & 22 & 55 & 67 & 19 & 388 & 38 & \\
\hline $\begin{array}{l}\text { Max. flow } \\
\text { M elótt (ml/sec) }\end{array}$ & 10,2 & 8,1 & 6,2 & 8,7 & 5,1 & 7,3 & - & - & - & - & 45,6 & 7,6 & \multirow{3}{*}{$45 \%$ csökkenés } \\
\hline $\begin{array}{l}\text { Max. flow } \\
\text { M után (ml/sec) }\end{array}$ & 19,6 & 20,3 & 21,0 & 18,3 & 10,8 & 11,4 & - & - & - & - & 101,4 & 16,9 & \\
\hline $\begin{array}{l}\text { Reziduum } \\
\text { M előtt (ml) }\end{array}$ & 120 & 60 & 160 & 150 & 40 & 140 & $\begin{array}{c}\text { incont } \\
. .\end{array}$ & ÁK & ÁK & ÁK & 670 & 111 & \\
\hline I-PSS M előtt & 8 & 10 & 7 & 11 & 9 & 5 & - & - & - & - & 50 & 8,3 & \multirow{2}{*}{$44 \%$ növekedés } \\
\hline I-PSS M után & 17 & 19 & 16 & 20 & 13 & 11 & - & - & - & - & 96 & 16 & \\
\hline
\end{tabular}


megbecsülhető, de a PSA-értéket megemelő gyulladásos komponens. A maximál flow átlagban 45\%-kal, 7,6 m/sec-ról 16,9 $\mathrm{m} /$ sec-re nőtt, de a szubjektív javulást jobban jelezte az I-PSS-pontok 8,3-ról 16-ra emelkedése. A reziduum eltúnt, a katéteres betegek spontán jól vizeltek és az egy inkontinencia megszúnt. A telefoninterjúban a betegek elégedettségüknek adtak hangot.

\section{Megbeszélés}

Az eljárás drága, hiszen mind a készülék, mind a lézerszál ára igen magas. Nem tárgya vizsgálódásunknak, hogy utánaszámoljunk, mennyibe kerül az évekig katétert viseló beteg szál- lítása, vizsgálata, kezelése, de valószínű vetekszik az egyszeri lézermútét árával, igaz induláskor nem igényel jelentős tőkebefektetést.

Az átlagos életkor hazánkban is emelkedik és még ennél is gyorsabban nő a BPH-s esetek társbetegségeinek száma. A gyógyszeres kezelés sikeres, de még öregebb korra tolja ki a kényszerű mútét idôpontját. A lézervaporizáció eléri a TUR sikerének arányát, de kisebb veszélyekkel jár és különösen indokolt antikoagulált betegeknél. Az összehasonlításnak bőséges az irodalma, de lézeroldalról ez a leginkább alkalmazott 180 wattos „green light” készüléket jelent (5). Kevert, azaz diódával gerjesztett Nd:YAG lézerrel kevesebb irodalom foglalkozik, ilyen hazai beszámolóról eddig nem volt tudomásunk.

\section{Irodalom}

1. Deák G, Bajory Z, Pajor L. Tranurethralis reszekció és diódalézer vaporizáció összehasonlítása BPH-kezelésben. Magy Urol 2010; 11 (4): 192-196.

2. Hueber PA, et al. Photoselective vaporization of the prostate for benign prostatic hyperplasia using the 180 watt system. J Urol 2015Aug; 194: 462-469. https://doi.org/10.1016/j.juro.2015.03.113

3. Kirschbaum A, et al. Comparison of local tissue damage: monopolar cutter versus Nd: Yag laser for lung parenchyma. J.C.V. and Th 2013 Oct; 14.

4. Thangasamy JA, et al. Photoselective vaporisation of the prostate using $80-\mathrm{W}$ and $120-\mathrm{W}$ laser versus transurethral resection of the prostate for benign prostatic hyperplasia: a systematic review with urethra-analysis from 2002 to 2012. Eur Urol 2012; 62: 315-323. https://doi.org/10.1016/j.eururo.2012.04.051

5. Valdivieso $R$, et al. Assessment of energy density usage during 180 $\mathrm{W}$ lithium triborate laser photoselective vaporization of the prostate for benign prostatic hyperplasia. BJU Int 2016. https:// doi.org/10.1111/bju. 13479 